Sascha Ruhle, Stefan Süß

\title{
Editorial: Workplace Flexibility
}

Within the last years, flexibility has been an ongoing issue for various fields of research and practice. Consequently, a considerable amount of literature dealing with the concept of flexibility has developed. Its diversity has led to various perspectives on dimensions and aspects of flexibility. However, two major fields of flexibility can be distinguished. On the one hand, the organizational perspective understands workplace flexibility as the degree of adaptability of an organization in an uncertain and changing environment (Dastmalchian \& Blyton, 2001). On the other hand, workplace flexibility can encompass the individual perspective of the workforce, especially the degree of flexibility regarding aspects of where, when, and how work is performed (Hill et al., 2008). Within both streams of research, various aspects of flexibility have been addressed, such as organizational structures (Feldman \& Pentland, 2003), type of employment (Lepak et al., 2003; Sayah \& Süß, 2013), management and strategic human resource management (Wright \& Snell, 1998), time and location of work (Allen et al., 2013), demands towards employees (Vahle-Hinz et al., 2013) and work (Ruiner et al., 2013), leadership (Barrow, 1976), and the role of Communication Technologies (Diaz et al., 2012). Regarding the consequences of flexibility, literature often assumes positive results for both individual and organization, when flexibility increases. For example, evidence has been found that flexibility at work is positively related to self-reported health (Butler et al., 2009). Furthermore, it can increase organizational attractiveness (Thompson et al., 2015), profit (Kesavan et al., 2014), and firm performance (Martínez Sánchez et al., 2007).

However, there is also a missing consensus and ongoing discussion regarding possible consequences of flexibility. Research has identified potential downsides of flexibility, such as blurred work-life boundaries (Pedersen \& Lewis, 2012), the risk of stigmatization (Cech \& Blair-Loy, 2014), unsupportive work climate and inequitable implementation of flexible work practices (Putnam et al., 2014). Other relationships, for example between flexibility and work-family conflict (Allen et al., 2013; Shockley \& Allen, 2007), remain unclear. Further, if flexibility is only an organizational facade (Eaton, 2003; Nystrom \& Starbuck, 1984) which is communicated but not lived in the organization, even more negative consequences such as violations of psychological contracts might occur, especially when flexibility is used as a facade to justify the transformation of standard work arrangements to non-

* Dr. Sascha Ruhle: Chair of Business Administration, in particular Organization Studies and Human Resource Management, Heinrich-Heine University Duesseldorf, Universitätsstraße 1, 40225 Düsseldorf, E-Mail: sascha.ruhle@hhu.de.

Prof. Dr. Stefan Süß: Chair of Business Administration, in particular Organization Studies and Human Resource Management, Heinrich-Heine University Duesseldorf, Universitätsstraße 1, 40225 Düsseldorf, E-Mail: stefan.suess@hhu.de. 
standard work arrangements. This special issue addresses some of the challenges described above.

The first contribution by Christian Grund, Axel Minten, and Nevena Toporova focuses on the relationship between individual and job-related characteristics and motivation assessments of temporary agency workers, who can be considered as an important and flexible asset for organizations. Drawing on a large sample from one of Germany's largest temporary work agencies, their study shows how the assessment of motivation and work morale, provided by the customer companies who employed the temporary agency worker, is dependent on individual and job-related characteristics. They highlight how further research should examine the progression of motivation during temporary work and in relation to regular employees.

Drawing on signaling theory, René Schmoll and Stefan Süß take a look at the separate and joint effect of temporal and spatial flexibility on organizational attraction. While first evidence suggests that flexibility can increase organizational attractiveness, an in-depth analysis of this effect is missing. Using an experimental, vignettebased study, they provide evidence that temporal and spatial flexibility have a separate effect. Instead of an interaction, they found an additive effect for the combination of both.

Also examining the consequences of temporal and spatial flexibility, the study from Setareh Zafari, Martina Hartner-Tiefenthaler, and Sabine Theresia Köszegi investigates the role of perceived organizational alignment as a contextual factor. They show that perceived organizational alignment moderates the positive effect of autonomy on work-related outcomes, such as work engagement, organizational identification, and job satisfaction. Especially based on the differing results for job satisfaction, they emphasize the need to carefully consider alignment measures in terms of employees' goals, as otherwise they can be perceived as too demanding, resulting in negative effects.

Overall, as was to be expected, these contributions open further questions regarding workplace flexibility. Both in the sphere of how individuals that are employed flexibly in organizations - such as temporary worker or freelancer-deal with this flexibility demands or the consequences of increasing flexible opportunities and demands in the day-to-day work. In our view, research would benefit from including further experimental investigations that focus on the differential effects of different types of flexibility

Finally, we would like to provide you with some insights into the editorial process of this special issue. We started this project in combination with the 2017 annual meeting of the German "Arbeitskreis Empirische Personal- und Organisationsforschung", where some of the contributors of this special issue presented early versions of their work. By December 31, 2017, we received seven contributions of which we selected five manuscripts to be included in the review process. Two 
manuscripts were desk rejected. After receiving eleven reviews, we provided all manuscripts with the opportunity for another revision. All authors followed our invitation to revise and resubmit and their manuscripts were then again externally reviewed, resulting in two additional rejections. After another editorial revise, we finally accepted three manuscripts. As such a rigor process would not have been possible without the timely, constructive, and helpful support provided by the reviewers, we would like to thank them for their commitment:

Dorothea Alewell; Matthias Baum; Kai Bormann; Wolfgang Güttel; Sven Hauff; Stephan Kaiser; Renate Ortlieb; Caroline Ruiner; Jost Sieweke; Marius Wehner; Uta Wilkens.

Düsseldorf, Januar 2019

Sascha Ruhle Stefan Süß

\section{Literature}

Allen, T. D., Johnson, R. C., Kiburz, K. M., \& Shockley, K. M. (2013). Work-family conflict and flexible work arrangements: Deconstructing flexibility. Personnel Psychology, 66(2), 345376.

Bal, P. M., \& Lange, A. H. de (2015). From flexibility human resource management to employee engagement and perceived job performance across the lifespan: A multisample study. Journal of Occupational and Organizational Psychology, 88(1), 126-154.

Barrow, J. C. (1976). Worker performance and task complexity as causal determinants of leader behavior style and flexibility. Journal of Applied Psychology, 61(4), 433-440.

Butler, A. B., Grzywacz, J. G., Ettner, S. L., \& Liu, B. (2009). Workplace flexibility, self-reported health, and health care utilization. Work \& Stress, 23(1), 45-59.

Cech, E. A., \& Blair-Loy, M. (2014). Consequences of flexibility stigma among academic scientists and engineers. Work and Occupations, 41(1), 86-110.

Dastmalchian, A., \& Blyton, P. (2001). Workplace flexibility and the changing nature of work: An introduction. Canadian Journal of Administrative Sciences/Revue Canadienne des Sciences de l'Administration, 18(1), 1-4.

Diaz, I., Chiaburu, D. S., Zimmerman, R. D., \& Boswell, W. R. (2012). Communication technology: Pros and cons of constant connection to work. Journal of Vocational Behavior, 80(2), 500-508.

Eaton, S. C. (2003). If you can use them: Flexibility policies, organizational commitment, and perceived performance. Industrial Relations: A Journal of Economy and Society, 42(2), 145-167.

Feldman, M. S., \& Pentland, B. T. (2003). Reconceptualizing organizational routines as a source of flexibility and change. Administrative Science Quarterly, 48(1), 94-118.

Hill, J. E., Grzywacz, J. G., Allen, S., Blanchard, V. L., Matz-Costa, C., Shulkin, S., \& Pitt-Catsouphes, M. (2008). Defining and conceptualizing workplace flexibility. Community, Work and Family, 11(2), 149-163. 
Kesavan, S., Staats, B. R., \& Gilland, W. (2014). Volume flexibility in services: The costs and benefits of flexible labor resources. Management Science, 60(8), 1884-1906.

Lepak, D. P., Takeuchi, R., \& Snell, S. A. (2003). Employment flexibility and firm performance: Examining the interaction effects of employment mode, environmental dynamism, and technological intensity. Journal of Management, 29(5), 681-703.

Martínez Sánchez, A., Pérez Pérez, M., Luis Carnicer, P. de, \& José Vela Jiménez, M. (2007). Teleworking and workplace flexibility: A study of impact on firm performance. Personnel Review, 36(1), 42-64.

Nystrom, P. C., \& Starbuck, W. H. (1984). Organizational Facades. Organizational Dynamics, 12(4), 53-65.

Pedersen, V. B., \& Lewis, S. (2012). Flexible friends? Flexible working time arrangements, blurred work-life boundaries and friendship. Work, Employment and Society, 26(3), 464-480.

Putnam, L. L., Myers, K. K., \& Gailliard, B. M. (2014). Examining the tensions in workplace flexibility and exploring options for new directions. Human Relations, 67(4), 413-440.

Ruiner, C., Wilkens, U., \& Küpper, M. (2013). Patterns of organizational flexibility in knowledge-intensive firms—-going beyond existing concepts. management revue, 24(3), 162-178.

Sayah, S., \& Süß, S. (2013). Conflict between work and life: The case of contract workers in the German IT and media sectors. management revue, 24(3), 222-244.

Shockley, K. M., \& Allen, T. D. (2007). When flexibility helps: Another look at the availability of flexible work arrangements and work-family conflict. Journal of Vocational Behavior, 71(3), 479-493.

Thompson, R. J., Payne, S. C., \& Taylor, A. B. (2015). Applicant attraction to flexible work arrangements: Separating the influence of flextime and flexplace. Journal of Occupational and Organizational Psychology, 88(4), 726-749.

Vahle-Hinz, T., Kirschner, K., \& Thomson, M. (2013). Employment-related demands and resources-new ways of researching stress in flexible work arrangements. management revue, 24(3), 199-221.

Wright, P. M., \& Snell, S. A. (1998). Toward a unifying framework for exploring fit and flexibility in strategic human resource management. Academy of Management Review, 23(4), 756-772. 